\title{
Papel do Setor da Recepção dos Serviços de Saúde Dentro da Política de Humanização do SUS
}

\author{
Vieira, Rebeca Yasmin Ribeiro; Silva, Lunagyla Nunes da; Ribeiro, Ana Carla \\ Andrade; Abud, Ana Cristina Freire \\ Universidade Federal de Sergipe — ryasminrv@gmail.com
}

Introdução a recepção de um serviço de saúde deve ser tratada de uma forma diferenciada dos outros serviços, visto que é o primeiro contato do usuário com o atendimento. no caso de uma unidade de urgência essa necessidade se faz ainda mais evidente, visto que o usuário que chega possui uma queixa mais imediata que exige uma maior atenção no primeiro contato. Objetivos Investigar o entendimento dos funcionários da recepção a respeito das políticas de humanização, bem como compreender a relação entre o setor da recepção com os outros setores da Unidade. Métodos Observação passiva da dinâmica do atendimento na recepção durante 8 horas semanais e aplicação de questionário com 12 perguntas subjetivas com funcionários do setor. Resultados Evidente falha na comunicação entre a recepção e outros setores da unidade e seus funcionários compreendem pouco ou quase nada da política de humanização do SUS além de desempenharem funções que não Ihes são devidas, como por exemplo, a classificação de risco. Conclusões: o setor da recepção é frequentemente deixado de lado e visto com inferioridade, seus funcionários acabam realizando por conta própria serviços negligenciados por outros setores, como a classificação de risco, o que também é influenciado pelo desconhecimento da politica de humanização fazendo com que não saibam onde se encaixam no serviço o que lhes é devido. Todos esses fatores só evidenciaram a necessidade de implementação de uma política de formação continuada dos profissionais de saúde, voltada para humanização e trabalho interprofissional com vistas ao aperfeiçoamento do atendimento prestado aos usuários do SUS, além de maiores investimentos na construção coletiva de protocolos para melhor comunicação entre os profissionais. Destacamos ainda que os profissionais da recepção demandam uma atenção humanizada para melhor compreensão do seu importante papel e para lidar com os diversos conflitos da relação saúde-doença, de forma a prestar um serviço mais qualificado à população, com amplo conhecimento e reflexão acerca dos direitos e deveres, seus e dos usuários.

\footnotetext{
Vieira, Rebeca Yasmin Ribeiro; Silva, Lunagyla Nunes da; Ribeiro, Ana Carla Andrade; Abud, Ana Cristina Freire. Papel do Setor da Recepção dos Serviços de Saúde Dentro da Política de Humanização do Sus. In: Anais do Congresso Internacional de Humanidades \& Humanização em Saúde [= Blucher Medical Proceedings, num.2, vol.1]. São Paulo: Editora Blucher, 2014. ISSN 2357-7282 DOI 10.5151/medpro-cihhs-10621
} 